\title{
Human capital investments as sources of skills: An analysis at different entrepreneurship phases
}

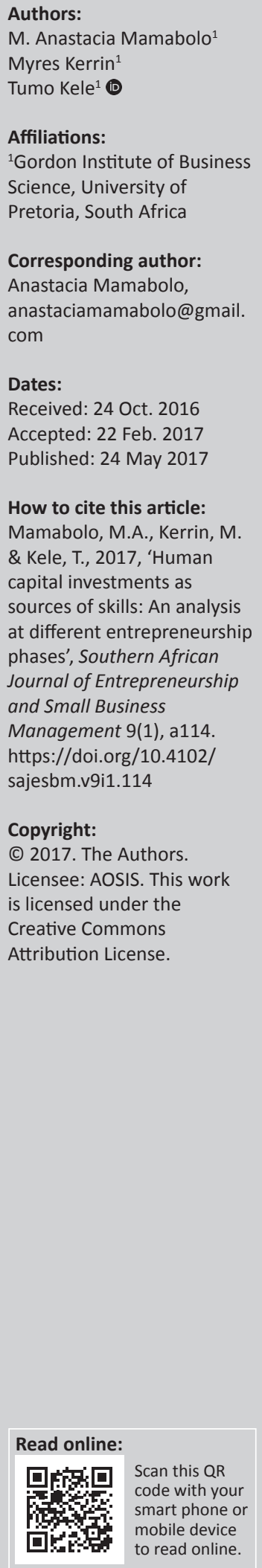

Background: Entrepreneurs need entrepreneurial skills to run their businesses. Skills can come from various sources, and the usage of the sources of skills can vary according to the different entrepreneurship phases.

Aim: Adopting a human capital theory perspective, this study determined the specific human capital investments as sources of skills needed by entrepreneurs across the different entrepreneurship phases. The sources of skills included work experience, formal education, entrepreneurship education and entrepreneurship experience.

Setting: Entrepreneurs at the different entrepreneurship phases which are nascent (entrepreneurs with ventures less than 3 months in existence), new business (entrepreneurs with ventures with more than 3 months but less than 3.5 years in existence) and established business (entrepreneurs with ventures more than 3.5 years in existence).

Method: The study employed a survey research design. An online questionnaire was used to collect the data.

Results: The results show that the sources of skills are used differently across the entrepreneurship phases. As entrepreneurs start businesses, in the nascent phase, the use of human capital investments (especially formal education) as a source of skills declines, thus creating a need to acquire more entrepreneurship-specific investments. In addition to acquiring skills from human capital investments, entrepreneurs learn skills from people in their social networks and self-taught skills which are used differently across the different entrepreneurship phases.

Conclusion: The findings indicate that the human capital investments are dynamic and change over time as the entrepreneurship phases unfold. Because there are different sources of skills for each entrepreneurship phase, entrepreneurs need to be treated according to their phases.

\section{Introduction}

Entrepreneurship is seen as a way of promoting economic growth through innovation and job creation (Dash \& Kaur 2012; Stenholm, Acs \& Wuebker 2013; Turton \& Herrington 2012). The significance of entrepreneurship as an engine of economic growth has attracted the interest of many governments and non-governmental organisations (World Bank 2012) and also entrepreneurship scholarship (Wiklund et al. 2011). This growing academic interest in entrepreneurship has also seen the application of human capital theory from the economics literature to study the success and failure of business ventures (Ucbasaran, Westhead \& Wright 2008; Unger et al. 2011).

Human capital theory (Becker 1964) has been applied in entrepreneurship to study the relationship between human capital investments and success in the identification and exploitation of opportunities (Davidsson \& Honig 2003; Ucbasaran et al. 2008; Unger et al. 2011). Most of the studies that applied human capital focused on either opportunity recognition or exploitation, with confined attention to singular phases of the entrepreneurship process, namely, the nascent, new business and established phases (Brixy, Sternberg \& Stüber 2012; Singer, Amorós \& Moska 2015). It has, however, been noted that a specific kind of human capital may be important in completing activities in one phase, while the same human capital may be insignificant in the subsequent phases within the entrepreneurial process (Brixy et al. 2012; Marvel, Davis \& Sproul 2014). As a result, this study argued in line with Marvel et al.'s study (2014) that there is a need to fully explore the differing dimensions of human capital (investments and skills) over distinct phases within the entrepreneurial process. 
One of the research questions that entrepreneurship research seeks to answer is 'where do entrepreneurial skills come from?' (Stuetzer, Goethner \& Cantner 2012). According to the human capital theory, skills come from the investments in education, work experience and industry experience. What is not clear from the literature is the role of human capital investments as the sources of skills in the different entrepreneurship phases. As such, this study aimed at determining the differing role of human capital investments across the different entrepreneurship phases.

A specific human capital investment as a source of skills will differ according to the entrepreneurship phase. Some investments may provide entrepreneurs with skills to start businesses, while others may be significant to produce skills that are needed to run and sustain the businesses. For example, Brixy et al. (2012) empirically discovered that formal education is more significant in identification and exploitation of opportunities than later when the business is established. Because entrepreneurship activities in the entrepreneurship phases are different (Amorós \& Bosma 2014; Reynolds \& Curtin 2008), entrepreneurs should be treated according to the phase they are in and the activities they are performing.

The findings of the study firstly showed that the use of human capital investments as sources of skills differ across the entrepreneurship phases. Secondly, as entrepreneurs start businesses, in the nascent phase, the use of human capital investments (especially formal education) as a source of skills declines, thus creating a need to acquire more entrepreneurship-specific investments. In the established phase, entrepreneurs use skills learnt from entrepreneurship education, mentoring and coaching. Thirdly, when the application of skills declines from the new business to the established phase, entrepreneurs seek additional sources of skills to counter the depreciating skill sets. Thirdly, in addition to acquiring skills from human capital investments, entrepreneurs learn skills from people in their social networks and self-taught skills which are used differently across the different entrepreneurship phases. And finally, the findings indicate that the human capital investments are dynamic and change over time as the entrepreneurship phases unfold. Because there are different sources of skills for each entrepreneurship phase, training institutions, scholars and policymakers need to treat entrepreneurs according to their phases.

\section{Literature review \\ Entrepreneurship phases}

In a seminal paper by Shane and Venkataraman (2000), entrepreneurship process is defined as the identification, evaluation and exploitation of opportunities. Entrepreneurship research has shown that there is no unified model of entrepreneurship process; however, a general consensus is that opportunity identification is one of the significant elements (Kirzner 1973; Shane \& Venkataraman 2000). Even though there is no agreement on the entrepreneurial process, there is empirical evidence that entrepreneurs actually engage in a process which, by virtue of the activities performed and the outcomes achieved, changes over time. The Panel Study of Entrepreneurial Dynamics (PSED) and the Global Entrepreneurship Monitor (GEM) provide some empirically tested entrepreneurship phases (Carter, Gartner \& Reynolds 1996; Herrington \& Kew 2017). The entrepreneurship phase is determined by the number of years that a business venture has been in existence and has paid salary, wages and any other payment to the owners (Herrington \& Kew 2017).

This study adopted the entrepreneurship phases as being the nascent, new business and established business (Herrington \& Kew 2017). The motivation for selecting the GEM entrepreneurship phases is that they are empirically tested rather than other theoretically derived frameworks (McMullen \& Dimov 2013; Moroz \& Hindle 2012) and are currently being adopted by other scholars in the field of entrepreneurship (Brixy et al. 2012; Wasdani \& Mathew 2014). Brixy et al. (2012) focused on the demographic and cognitive characteristics of entrepreneurs, while Wasdani and Mathew (2014) studied opportunity recognition in the different entrepreneurship phases.

Nascent phase entrepreneurs are individuals who take steps to create a venture, such as looking for equipment or a location, organising a start-up team, preparing a business plan or beginning to save money (Bergmann \& Stephan 2013; Carter et al. 1996). These ventures are less than 3 months old (Herrington \& Kew 2017). New business phase entrepreneurs are those former nascent entrepreneurs who have been in business for more than 3 months, but less than 3.5 years (Herrington \& Kew 2017; Turton \& Herrington 2012). New business entrepreneurs are owning and managing a business, implementing the business plan, running the business on day-to-day basis, planning for growth, innovation, implementing organisational systems and hiring employees (Man, Lau \& Chan 2002; Trevelyan 2011).

The established phase entrepreneurs are those who have been in business for more than 3.5 years (Herrington \& Kew 2017; Kelley, Singer \& Herrington 2012). Established entrepreneurs are focused on owning and managing a business, environmental scanning for new opportunities, quality control, evaluating ideas with existing frameworks, refining existing production processes, creating organisational structures to speed up production, creating new products and provision of a more stable base of employment (Man et al. 2002; Herrington \& Kew 2017; Trevelyan 2011). While nascent and new business entrepreneurs contribute to dynamism and innovation in an economy, established businesses and their owner-managers often provide stable employment and exploit the knowledge and social capital accumulated in past experiences (Amorós \& Bosma 2014). It should be noted that the transition from the nascent to new business and thereafter the established phase is to some extent fluent and depends on the specific situations (Brixy et al. 2012). For example, in some situations entrepreneurs 
may take longer to generate income, consequently staying longer in the nascent phase. The challenge with the entrepreneurship phases is that there is no clear evidence as to how and when entrepreneurs make a transition from one phase to the next.

\section{Human capital theory}

According to Becker's (1964) human capital theory, human capital is the skills and knowledge manifested as ability to execute a function in order to create economic value (Ucbasaran et al. 2008; Unger et al. 2011). Skills and knowledge can be human capital outcomes acquired through investments in formal and non-formal schooling, practical learning and work experience, which contribute to productivity and success (Becker 1964; Silva 2007; Unger et al. 2011). The human capital investments can be generic or entrepreneurship-specific. The generic investments which are not related to any entrepreneurship activities are formal education and work experience, while entrepreneurshipspecific investments related to entrepreneurship activities are start-up experience, business-ownership experience, managerial capabilities, entrepreneurial capabilities and technical capabilities (Becker 1964; Ucbasaran et al. 2008).

\section{General human capital investments}

Human capital theory is based on the assumption that formal education and work experience should be considered as general human capital investments which produce knowledge and skills (Becker 1964).

Formal education: It emerged as a significant source of knowledge and skills and, amongst others, confidence to execute entrepreneurial activities (Ucbasaran et al. 2008). Shane (2003) suggested that educated entrepreneurs may use the knowledge and skills acquired through the educational system for identification and pursuit of opportunities. There are contradictory observations with regard to education. One empirical view argued that the probability of educated individuals to create business ventures is high (Amorós \& Bosma 2014), while opposing views argued that they are unlikely to start their own business ventures (Van der Sluis, Van Praag \& Vijverberg 2008). Another empirical analysis of 380 nascent entrepreneurs showed that those with formal education are probable to discover entrepreneurial opportunities but may not be successful in exploiting process (Davidsson \& Honig 2003). In a developing economy, studies have shown that entrepreneurs with higher levels of education are both more likely to start a business and ensure its sustainability (Herrington, Kew \& Kew 2014). These authors focused on the nascent phase, indicating that the significance of formal education in producing skills applied by entrepreneurs in the different entrepreneurship phases other than the nascent is yet to be explored (Marvel et al. 2014):

Hypothesis 1: Entrepreneurs in the nascent phase use skills acquired from formal education the most when compared to entrepreneurs in the new business and established business phases.
Work experience: It is represented by tacit knowledge is of paramount importance in the process of entrepreneurship (Davidsson \& Honig 2003; Gabrielsson \& Politis 2012; Polanyi 1966) and may produce managerial skills to start new businesses (Shane 2000). The indicator of work experience is the number of years of experience, number of prior full-time jobs and achievement level which can simply be regarded as position occupied (Gimeno et al. 1997; Unger et al. 2011). Rather than having similar work experience as it is assumed in human capital theory, empirical evidence indicates that varied work experience is an added advantage for better opportunity identification, exploitation and running of a successful business venture (Ganotakis 2012). This was confirmed through empirical study that founders with variety of work experiences, to be specific, managerial experience, are more likely to have developed the necessary skills to organise the business and have a greater chance of success in the start-up phase (Baptista, Karaöz \& Mendonça 2014). Although there is paucity of evidence of the role of work experiences beyond start-up, this study proposes that work experience may be a source of skills needed by entrepreneurs in different entrepreneurship phases to carry out entrepreneurial activities such as organising equipment and facilities, hiring employees, seeking financial support, forming legal entity, owning and managing a business, environmental scanning, implementing organisational systems, quality control and evaluating ideas with existing frameworks (Amorós \& Bosma 2014; Man et al. 2002; Reynolds \& Curtin 2008; Trevelyan 2011):

Hypothesis 2: Entrepreneurs in the nascent phase use skills acquired from work experience the most when compared to entrepreneurs in the new business and established phases.

\section{Entrepreneurship-specific human capital investments}

Empirical evidence indicated that entrepreneurship-specific investments, such as earlier experience in starting up a business, entrepreneurship education and the membership of an association for small business founders, generate more promising start-ups and enhance performance (Baptista et al. 2014; Bosma et al. 2004).

Prior entrepreneurship experience: The literature indicates that previous start-up experience incorporates knowledge and skills gained either in business or when creating a venture (Morris et al. 2012) and also enhances both the ability to recognise viable opportunities and overcome the liability of newness challenge as a venture is created (Parker 2013; Politis 2008). Recent empirical studies suggested that individuals who have accrued experience as business owners should possess higher accumulated levels of human capital represented by better managerial and technical skills (Baptista et al. 2014; Ucbasaran et al. 2008). This suggests that prior entrepreneurial experience is a source of significant skills for the successful implementation of the entrepreneur's start-up efforts but will not necessarily ensure the entrepreneur's persistence with these efforts to other phases (Dimov 2010). Entrepreneurs who are established and in the new business phase may have entrepreneurial experiences 
that enable them to generate knowledge from one setting and apply it effectively to a new situation (Toft-Kehler, Wennberg \& Kim 2014). Therefore, this study investigated how prior entrepreneurship experience is utilised as a source of skills across the different entrepreneurship phases:

Hypothesis 3: The entrepreneurs in the nascent phase use skills acquired from previous business experience the most when compared with entrepreneurs in the new business and established business phases.

Entrepreneurship education: It is human capital investment which produces explicit knowledge and skills. A recent metaanalytical study by Martin, McNally and Kay (2013) showed that there is a relationship between entrepreneurship education and training, related human capital assets and entrepreneurial outcomes. The relationship is stronger for academic-focused interventions rather than training-focused interventions. Chang, Liu and Chiang (2014) in their empirical study highlighted that well established entrepreneurship courses have a significant impact with regard to enhancing opportunity recognition. However, this relationship may be mediated by other variables like entrepreneurial alertness. The findings of data collected from 170 entrepreneurs showed that not only does entrepreneurship training provide skills but also it appears to create openness, confidence and trust amongst the participants (Elmuti, Khoury \& Omran 2012). Therefore, this study investigated the use of entrepreneurship education as a source of skills for entrepreneurs in the later entrepreneurship phases:

Hypothesis 4: The entrepreneurs in the established phase use skills acquired from entrepreneurship education more than entrepreneurs in the nascent and new business phase.

\section{Social actors}

In addition to acquiring skills from human capital investments, there are other sources from which entrepreneurs acquire skills. Some of the entrepreneurs learn skills from their social networks such as family and friends, and those with mentors and coaches in their networks, they learn skills from them (Aldrich \& Yang 2014; Putnam 2001). Family can provide resources needed to start the business (Davidsson \& Honig 2003) and they can also influence their children's career choice (Aldrich \& Yang 2014). The role of mentorship increases the decision to join early-stage ventures or to start entrepreneurial careers, especially for entrepreneurs whose parents are not entrepreneurial (Eesley \& Wang 2017). The experienced entrepreneurs can teach aspiring entrepreneurs tacit knowledge such as evaluation of business opportunities, forming teams and navigating external investments (Eesley \& Wang 2017; St-Jean et al. 2016). Also, entrepreneurs who are in business, contrary to others with no entrepreneurial experience, support opportunity identification and exploitation (St-Jean et al. 2016). Therefore, this study suggests that:

Hypothesis 5a: Entrepreneurs in the nascent phase use skills learnt from family and friends more than entrepreneurs in the new business and established business phases.
Hypothesis 5b: Entrepreneurs in the nascent phase use skills acquired from coaches and mentors more than entrepreneurs in the new business and established business phases.

\section{Self-taught}

Entrepreneurs read about skills that successful entrepreneurs have and thereafter implement or imitate the same skills in their businesses (Aldrich \& Yang 2014; Baron \& Ensley 2006; Rae 2005). Unlike entrepreneurs in the established business phases who generally follow or modify the routines that they have developed, nascent entrepreneurs start mostly in a blank state (Aldrich \& Yang 2014). The nascent entrepreneurs read about what successful entrepreneurs have done and imitate them, especially those who begin without enough knowledge and skills. Finally, some of the skills are selftaught as they go through failure and experimentation in setting and running their businesses (Markman \& Baron 2003; Yusuf 2012). Therefore, the study determines how selftaught skills through reading books and mistakes and failure are used in the different entrepreneurship phases:

Hypothesis 6a: Entrepreneurs in nascent phase use the skills acquired from failure and mistakes more than entrepreneurs in the new business and established business phases.

Hypothesis 6b: Entrepreneurs in nascent phase use the skills learnt from reading books more than entrepreneurs in the new business and established business phases.

\section{Research design and methodology}

The research question of the study is the following: how are the sources of skills used differently across the entrepreneurship phases?

The objectives of the study are:

- Objective 1: To determine the use of formal education, work experience, entrepreneurship education and prior entrepreneurship experience as the sources of skills used in the different entrepreneurship phases.

- Objective 2: To determine the use of social actors, that is mentors and coaches, and family and friends as sources of skills across the different entrepreneurship phases.

- Objective 3: To investigate the use of self-taught skills from failure and mistakes and reading books across the different entrepreneurship phases.

\section{Research design}

The quantitative research design was used in the study. The study adopted a probability sampling strategy, in which the possibility of each unit to be selected from the population is known and usually equal for all cases (Teddlie \& Yu 2007). This strategy is implemented when selecting a relatively large number of units from a population, or from specific subgroups of a population (Tashakkori \& Teddlie 2003; Teddlie \& Yu 2007). A probability sampling was used to ensure that the whole population was represented. The sample consisted of the three groups of entrepreneurs who were in the nascent, new business and established business 
phases. Using the GEM sampling strategy, nascent businesses paid salaries in any kind for less than 3 months, new businesses paid salaries in any kind for more than 3 months but less than 3.5 years and established businesses paid salaries in any kind for more than 3.5 years (Herrington \& Kew 2017; Kelley et al. 2012; Turton \& Herrington 2012).

The human capital was measured by formal education, entrepreneurship education, work experience and prior entrepreneurship experience, while other sources were measured as family and friends, mentors and coaches, selftaught from failure and mistakes and reading books.

\section{Research method}

The quantitative survey data were collected using a standardised, structured, self-administered online questionnaire which was completed by entrepreneurs owning the business ventures. Experts in the field of entrepreneurship were requested to give input on the designed instrument and determine if it measured the concepts intended. The comments were made and the instrument was amended accordingly. The questionnaire had closed-ended questions with 5-point Likert scales, from which respondents were required to select one of five options. The Likert scale measures responses along a dimension from positive to negative, whereby the following possible answers are selected: strongly approve, approve, undecided, disapprove and strongly disapprove (Likert 1932). The responses expected in this study with regard to the use of the skills acquired from human capital investments ranged from $1=$ never, $2=$ almost never, 3 = sometimes, $4=$ almost every day to $5=$ every day. In employing the ordinal scale of measurement, the researcher was able to interrogate the extent to which respondents thought they used skills that they obtained from the human capital investments, social actors and self-teaching.

An invitation to participate in the study together with the survey link on SurveyMonkey was emailed to entrepreneurs. The list of the entrepreneurs was sourced from a private organisation that works with entrepreneurs in South Africa. The list had their email addresses, telephone numbers and contact addresses. In the first week of sending out the survey email, 116 entrepreneurs responded. At the end of 1 month of data collection, there were 235 responses comprising 56 nascent, 54 new business and 125 established entrepreneurs. Because the established phase had a highest number of entrepreneurs than the nascent and new business phase, a random sample of 58 entrepreneurs was selected from the 125 established entrepreneurs so as to balance the number of entrepreneurs in the phases. After balancing the phases, the final sample had 168 responses.

The quantitative phase was a nationwide survey, capturing data from entrepreneurs in all South African provinces: Gauteng, Limpopo, Mpumalanga, North-West, Northern Cape, Western Cape, KwaZulu-Natal, Free State and Eastern Cape.

\section{Unit of analysis}

The unit of analysis was the individual entrepreneur. The study focused on entrepreneurs in the three different entrepreneurship phases; therefore, the levels of analysis included the nascent, new business and established business phases.

\section{Data analysis}

The survey responses were consolidated and then exported to IBM-SPSS statistical software for analysis. Kruskal-Wallis test was used to provide clear comparisons of the use of skills across the three phases and to test the hypotheses. The Kruskal-Wallis test is a non-parametric test applied to rank the data and compare the median ranks of three or more groups when the level of measurement is ordinal (Cunningham \& Aldrich 2011). The Kruskal-Wallis test findings, which showed that entrepreneurship phases had unequal application of skills, were further analysed using the Mann-Whitney $U$ test to detect the two-by-two group differences. Mann-Whitney $U$ test is a non-parametric test utilised to provide the statistical evidence that two sampled populations are statistically different (Cunningham \& Aldrich 2011).

\section{Research findings}

As part of the screening process or inclusion test for the survey, respondents were asked if they had an operational business or not. Respondents without an operational business at the time the survey was conducted were automatically disqualified from participating. There were 108 (64\%) males and $60(30 \%)$ females who participated in the study. This was incidentally aligned with national and global studies, showing that males are more entrepreneurial than females (Herrington et al. 2014). Entrepreneurs were asked to locate themselves within one of the entrepreneurship phases. The measures used to determine entrepreneurship phases were in line with the GEM classification and include the period the business has existed and duration of paying salaries of any kind (Herrington et al. 2014). The entrepreneurs were 56 $(33 \%)$ in the nascent, $54(32 \%)$ in the new business and 58 $(35 \%)$ in the established business phases.

The Kolmogorov-Smirnov test for normality was performed on the human capital investment variables to determine the distribution of the data. The output of the results had a $p=$ 0.000 which indicated that the variables were not normally distributed; therefore, the analysis of the data required nonparametric tests. After the normality test, the Kruskal-Wallis test was performed to determine the difference in the application of skills acquired from the human capital investments across the three entrepreneurship phases. The results of the Kruskal-Wallis test are presented in Table 1.

The results of the Kruskal-Wallis test depicted in Table 1 show that the skills learnt from work experience $(p=0.260)$ and formal education $(p=0.249)$ are applied equally across 
TABLE 1: Kruskal-Wallis test for human capital investments and social actors.

\begin{tabular}{|c|c|c|c|c|c|c|}
\hline $\begin{array}{l}\text { Human capital } \\
\text { and social actors }\end{array}$ & $\begin{array}{l}\text { Entrepreneurship } \\
\text { phase }\end{array}$ & $N$ & $\begin{array}{l}\text { Mean } \\
\text { rank }\end{array}$ & $\begin{array}{l}\text { Chi- } \\
\text { square }\end{array}$ & $d f$ & $\begin{array}{l}\text { Asymp. } \\
\text { Sig }\end{array}$ \\
\hline \multirow[t]{4}{*}{ Formal education } & Nascent & 56 & 91.36 & & \multirow{4}{*}{2} & \multirow{4}{*}{0.249} \\
\hline & New business & 54 & 85.56 & & & \\
\hline & Established & 58 & 76.90 & & & \\
\hline & Total & 168 & - & 2.777 & & \\
\hline \multirow[t]{4}{*}{ Work experience } & Nascent & 56 & 83.11 & & \multirow{4}{*}{2} & \multirow{4}{*}{0.260} \\
\hline & New business & 54 & 78.15 & & & \\
\hline & Established & 58 & 91.76 & & & \\
\hline & Total & 168 & - & 2.696 & & \\
\hline \multirow{4}{*}{$\begin{array}{l}\text { Entrepreneurship } \\
\text { education }\end{array}$} & Nascent & 56 & 78.37 & & \multirow{4}{*}{2} & \multirow{4}{*}{0.000} \\
\hline & New business & 54 & 68.15 & & & \\
\hline & Established & 58 & 105.65 & & & \\
\hline & Total & 168 & - & 19.497 & & \\
\hline \multirow{4}{*}{$\begin{array}{l}\text { Previous } \\
\text { entrepreneurship } \\
\text { experience }\end{array}$} & Nascent & 56 & 73.73 & & \multirow{4}{*}{2} & \multirow{4}{*}{0.017} \\
\hline & New business & 54 & 80.92 & & & \\
\hline & Established & 58 & 98.23 & & & \\
\hline & Total & 168 & - & 8.122 & & \\
\hline \multirow{4}{*}{$\begin{array}{l}\text { Self-taught (failure } \\
\text { and mistakes) }\end{array}$} & Nascent & 56 & 92.46 & & \multirow{4}{*}{2} & \multirow{4}{*}{0.000} \\
\hline & New business & 54 & 111.61 & & & \\
\hline & Established & 58 & 51.57 & & & \\
\hline & Total & 168 & - & 49.967 & & \\
\hline \multirow{4}{*}{$\begin{array}{l}\text { Self-taught } \\
\text { (reading books) }\end{array}$} & Nascent & 56 & 92.02 & & \multirow{4}{*}{2} & \multirow{4}{*}{0.000} \\
\hline & New business & 54 & 97.86 & & & \\
\hline & Established & 58 & 64.80 & & & \\
\hline & Total & 168 & - & 16.311 & & \\
\hline \multirow[t]{4}{*}{ Family and friends } & Nascent & 56 & 72.86 & & \multirow{4}{*}{2} & \multirow{4}{*}{0.009} \\
\hline & New business & 54 & 81.33 & & & \\
\hline & Established & 58 & 98.69 & & & \\
\hline & Total & 168 & - & 9.317 & & \\
\hline \multirow{4}{*}{$\begin{array}{l}\text { Mentors and } \\
\text { coaches }\end{array}$} & Nascent & 56 & 73.00 & & \multirow{4}{*}{2} & \multirow{4}{*}{0.000} \\
\hline & New business & 54 & 63.29 & & & \\
\hline & Established & 58 & 115.35 & & & \\
\hline & Total & 168 & - & 39.914 & & \\
\hline
\end{tabular}

$d f$, degrees of freedom; Asymp.Sig, asymptotic significance.

the entrepreneurship phases, whereas the rest of the skills learnt from entrepreneurship education $(p=0.000)$, previous entrepreneurship experience $(p=0.017)$, self-taught through failure $(p=0.000)$ and reading books $(p=0.000)$, family and friends $(p=0.009)$ and mentors and coaches $(p=0.000)$ are not used equally across the different entrepreneurship phases. The Kruskal-Wallis test findings, which showed that the sources of the skills were used differently, were further analysed using the Mann-Whitney U test to determine twoby-two group differences. The results of the Mann-Whitney $\mathrm{U}$ test are presented in Table 2.

\section{Entrepreneurship education}

There is no difference in the application of skills learnt from entrepreneurship education across the nascent and new business phases $(p=0.246)$. The difference in the application is seen in the new business phase and established phase, with the established phase having a higher mean than the new business phase $[p=0.010 ; \overline{\mathrm{X}}($ established $=68.48)>\overline{\mathrm{X}}($ new business $=43.43)]$. When the established phase was compared with the nascent phase, the results showed that the usage of skills learnt from entrepreneurship education is higher in the established phase than in the nascent phase $[p=0.000$; $\overline{\mathrm{X}}($ nascent $=66.66)>\overline{\mathrm{X}}($ established $=48.01)]$.
TABLE 2: Mann-Whitney $U$ test for human capital investments and social actors.

\begin{tabular}{|c|c|c|c|c|c|}
\hline $\begin{array}{l}\text { Human capital } \\
\text { investment and } \\
\text { social actors }\end{array}$ & $\begin{array}{l}\text { Entrepreneurship } \\
\text { phase }\end{array}$ & $N$ & $\begin{array}{l}\text { Mean } \\
\text { rank }\end{array}$ & $\begin{array}{l}\text { Sum of } \\
\text { ranks }\end{array}$ & $\begin{array}{l}\text { Chi- } \\
\text { square }\end{array}$ \\
\hline \multirow{9}{*}{$\begin{array}{l}\text { Entrepreneurship } \\
\text { education }\end{array}$} & Nascent & 56 & 58.86 & 3296.00 & \\
\hline & New business & 54 & 52.02 & 2809.00 & 0.246 \\
\hline & Total & 110 & - & - & \\
\hline & New business & 54 & 43.63 & 2356.00 & \\
\hline & Established & 58 & 68.48 & 3972.00 & 0.010 \\
\hline & Total & 114 & - & - & \\
\hline & Nascent & 56 & 48.01 & 2688.50 & \\
\hline & Established & 58 & 66.66 & 3866.50 & 0.000 \\
\hline & Total & 112 & - & - & \\
\hline \multirow{9}{*}{$\begin{array}{l}\text { Previous } \\
\text { entrepreneurship } \\
\text { experience }\end{array}$} & Nascent & 56 & 53.46 & 2993.50 & \\
\hline & New business & 54 & 57.62 & 48.01 & 0.483 \\
\hline & Total & 110 & - & - & \\
\hline & New business & 54 & 50.80 & 2743.00 & \\
\hline & Established & 58 & 61.81 & 8585.00 & 0.063 \\
\hline & Total & 112 & - & - & \\
\hline & Nascent & 56 & 48.78 & 2731.50 & \\
\hline & Established & 58 & 65.92 & 3823.50 & 0.040 \\
\hline & Total & 114 & - & - & \\
\hline \multirow{9}{*}{$\begin{array}{l}\text { Self-taught (failure } \\
\text { and mistakes) }\end{array}$} & Nascent & 56 & 48.99 & 2743.50 & \\
\hline & New business & 54 & 62.25 & 3361.50 & 0.014 \\
\hline & Total & 110 & - & - & \\
\hline & New business & 54 & 76.86 & 4150.50 & \\
\hline & Established & 58 & 37.54 & 2177.50 & 0.000 \\
\hline & Total & 112 & - & - & \\
\hline & Nascent & 56 & 71.97 & 4030.50 & \\
\hline & Established & 58 & 43.53 & 2524.50 & 0.000 \\
\hline & Total & 114 & - & - & \\
\hline \multirow{9}{*}{$\begin{array}{l}\text { Self-taught } \\
\text { (reading books) }\end{array}$} & Nascent & 56 & 53.44 & 2992.50 & \\
\hline & New business & 54 & 57.64 & 3112.50 & 0.464 \\
\hline & Total & 110 & - & - & \\
\hline & New business & 54 & 67.72 & 3657.00 & \\
\hline & Established & 58 & 46.05 & 2671.00 & 0.000 \\
\hline & Total & 112 & - & - & \\
\hline & Nascent & 56 & 67.08 & 3756.50 & \\
\hline & Established & 58 & 48.25 & 2798.50 & 0.020 \\
\hline & Total & 114 & - & - & \\
\hline \multirow[t]{9}{*}{ Family and friends } & Nascent & 56 & 52.77 & 2955.00 & \\
\hline & New business & 54 & 58.33 & 3150.00 & 0.330 \\
\hline & Total & 110 & - & - & \\
\hline & New business & 54 & 50.50 & 2727.00 & \\
\hline & Established & 58 & 62.09 & 3601.00 & 0.047 \\
\hline & Total & 112 & - & - & \\
\hline & Nascent & 56 & 48.59 & 2721.00 & \\
\hline & Established & 58 & 66.10 & 3834.00 & 0.003 \\
\hline & Total & 114 & - & - & \\
\hline \multirow{9}{*}{$\begin{array}{l}\text { Mentors and } \\
\text { coaches }\end{array}$} & Nascent & 56 & 58.61 & 3282.00 & \\
\hline & New business & 54 & 52.28 & 2823.00 & 0.278 \\
\hline & Total & 110 & - & - & \\
\hline & New business & 54 & 38.51 & 2079.50 & \\
\hline & Established & 58 & 73.25 & 4248.50 & 0.000 \\
\hline & Total & 112 & - & - & \\
\hline & Nascent & 56 & 42.89 & 2402.00 & \\
\hline & Established & 58 & 71.60 & 4153.00 & 0.000 \\
\hline & Total & 114 & - & - & \\
\hline
\end{tabular}

\section{Prior entrepreneurship experience}

The application of skills learnt from previous entrepreneurship experience in the nascent and new business phases is not statistically different $(p=0.483)$. There is a statistically significant difference in the application 
of skills learnt from previous entrepreneurship education between the nascent and established phases $(p=0.040)$. The established phase has a higher mean than the nascent phase $[\overline{\mathrm{X}}($ nascent $=48.78)<\overline{\mathrm{X}}($ established $=65.92)]$. The findings also showed that there is no difference between the usage of skills learnt from previous entrepreneurship experience in the new business and established phases, with the new business phase having a lower mean $[p=0.063 ; \overline{\mathrm{X}}($ new business $=50.80)<\overline{\mathrm{X}}($ established $=61.81)]$.

\section{Family and friends}

The comparison of the nascent and new business phases did not show any statistically significant difference $(p=0.330)$. The results showed a difference in the application of skills learnt from family and friends between the new business and established business phases, with the established phase having a higher mean than the new business phase $[p=0.047$; $\overline{\mathrm{X}}($ new business $=50.51)<\overline{\mathrm{X}}($ established $=62.09)]$. Further analysis showed that entrepreneurs in the established phase apply more skills acquired from family and friends than entrepreneurs in the nascent phase $[p=0.003 ; \overline{\mathrm{X}}$ (nascent $=$ $48.59)<\overline{\mathrm{X}}($ established $=66.10)]$.

\section{Mentorship and coaching}

Table 2 showed that there is no statistically significant difference in the application of skills learnt from mentors and coaches between the nascent and new business phase $(p=0.278)$. Entrepreneurs in the established phase apply skills acquired from mentors and coaches more than entrepreneurs in the new business phase $[p=0.000 ; \overline{\mathrm{X}}$ (new business $=38.51)<\overline{\mathrm{X}}($ established $=73.25)]$. When compared with the nascent phase, established entrepreneurs have a higher rank mean $[p=0.000 ; \overline{\mathrm{X}}($ nascent $=42.89)<$ $\overline{\mathrm{X}}($ established $=71.60)$ ], which simply means that they apply skills learnt from mentors and coaches more than entrepreneurs in the nascent phase.

\section{Self-taught (failures and mistakes)}

Entrepreneurs were asked about how they apply skills learnt from failure. The results showed that the application of the skills learnt from failure and mistakes is different across all the entrepreneurship phases (all $p$-values are greater than 0.005). The results showed that the new businesses have a higher rank mean than the established businesses, meaning that entrepreneurs in the new business phase use skills learnt from failure and mistakes to a greater extent $[p=0.000$; $\overline{\mathrm{X}}($ established $=37.54)<\overline{\mathrm{X}}($ new business $=76.86)]$. The nascent phase also has a higher mean than the established phase $[p=0.00 ; \overline{\mathrm{X}}($ nascent $=71.97)>\overline{\mathrm{X}}($ established $=43.53)]$. The comparison of the nascent phase and new business phase showed that entrepreneurs in the new business phase use more skills learnt from failure and mistakes than those in the nascent phase $[p=0.014 ; \overline{\mathrm{X}}($ new business $=62.25)$ $>\overline{\mathrm{X}}($ nascent $=48.99)]$.

\section{Self-taught (reading books)}

Regarding the use of skills learnt from reading books, the results showed a difference between the new business and established phases $(p=0.000)$. The new business phase has a higher mean than the established phase $[\overline{\mathrm{X}}$ (new business $=$ $67.72)>\bar{X}($ established $=46.05)]$. In addition, entrepreneurs in the nascent phase apply more skills acquired from reading books than entrepreneurs in the established phase $[p=0.000$; $\overline{\mathrm{X}}($ nascent $=67.08)>\overline{\mathrm{X}}($ established $=48.25)]$.

Figure 1 shows that formal education is used more as a source of skills by entrepreneurs in the nascent phase than those in the new business and established phases. The use of formal education as a source of skills declines as the entrepreneurship phases unfold. Entrepreneurs in the nascent and new business phase use the skills obtained from work experience more than those in the established business phase. Entrepreneurship education and prior entrepreneurship experience are a more significant source

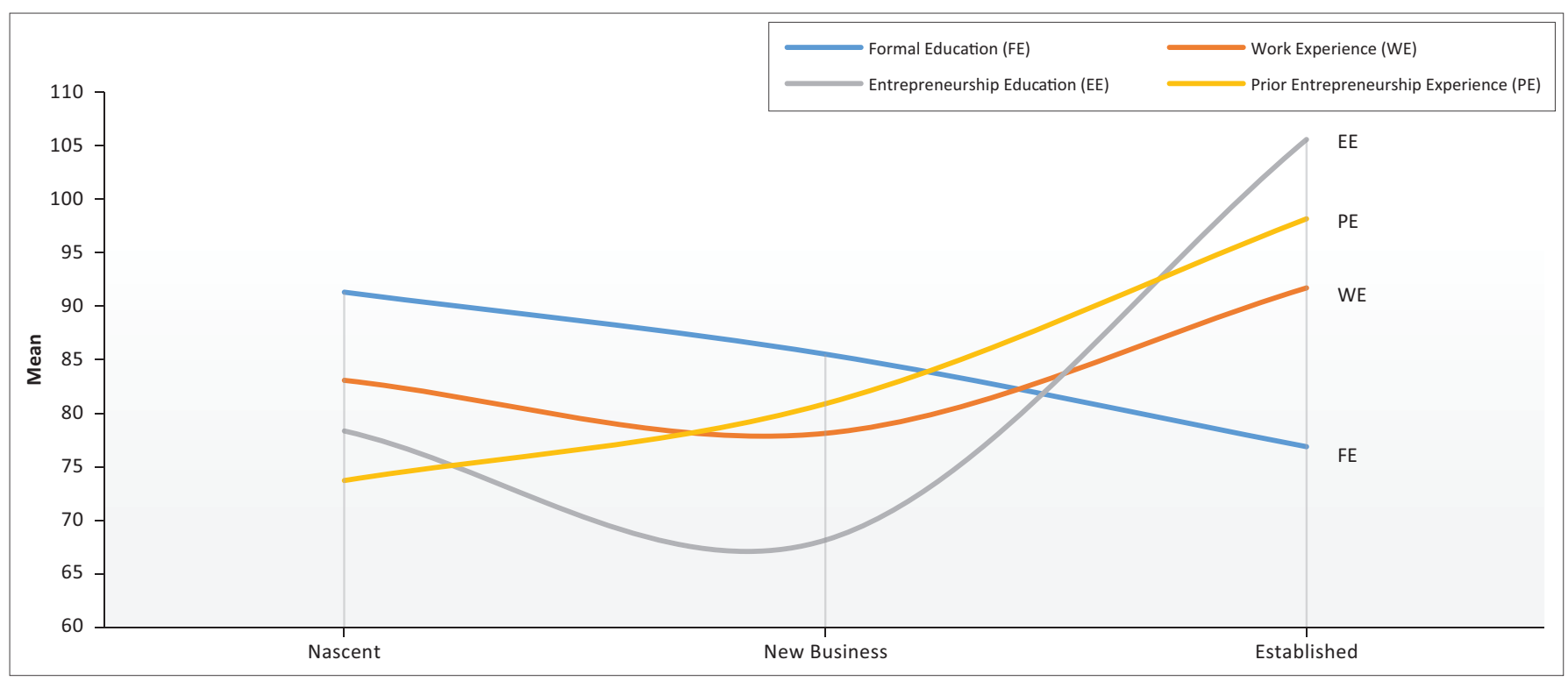

FIGURE 1: Human capital investments utility across the entrepreneurship phases. 
of skills for entrepreneurs in the established phase than those in the nascent and new business phase.

An overall analysis of the human capital investments showed that when a nascent entrepreneur starts a business, he or she uses skills from human capital investments (especially formal education). As the entrepreneur transitions from the nascent phase to new business phase, the human capital investments which provided skills to start the business become less important, thus creating a demand to update the human capital investments for the next entrepreneurship phase. Figure 2 shows how the use of human capital investments as sources of skills changes as the entrepreneurship phases unfold.

A decline in the utility of human capital investments, for example, formal education as sources of skills in the new business phase, stimulates entrepreneurs to seek out entrepreneurship courses, as well as mentoring and coaching programmes. Therefore, the human capital investments which were the sources of skills when the business started become obsolete as the entrepreneurship phases unfold, consequently creating a demand on entrepreneurs to look for other sources. In essence, established entrepreneurs have better access to entrepreneurship education because the enterprise development programme focuses on skills that are more relevant to established entrepreneurs rather than nascent or new business entrepreneurs.

Figure 3 displays the use of social actors and human capital investments as sources of skills across the entrepreneurship phases. The study suggests a U-shaped curvilinear relationship of the use of skills acquired from the human capital investments and social actors across the entrepreneurship phases. This means that human capital investments and social actors serve as sources of skills when the business starts; however, they become obsolete as the entrepreneurship phases unfold. If an entrepreneur has access to other human capital investments such as entrepreneurship education, they will increase the skills needed to run their businesses, especially in the established business phase.

Figure 3 also illustrates that the application of self-taught skills across the phases is an inverted U-shaped curvilinear relationship; thus, self-taught skills are applied the most in the nascent and new business phases than in the established phase. Because of limited or lack of access to other significant sources of skills such as mentorship and entrepreneurship education, entrepreneurs starting businesses rely on their own learnings from failure, mistakes and reading entrepreneurship books. However, as the entrepreneurship phases unfold, they realise the need to get additional training and to form social networks, hence the decline in the utility of self-taught skills and corresponding increase in the utility of human capital investments and social networks in the established phase.

\section{Discussion}

\section{Hypothesis 1: Formal education}

The hypothesis was not supported as there was no statistically significant difference to suggest that skills acquired from formal education were used differently across the different entrepreneurship phases. Although there was no statistically significant difference in application, entrepreneurs in the nascent phase applied skills learnt from formal education to a greater extent than entrepreneurs in the new business and established phases. These findings are consistent with a meta-analytical study by Unger et al. (2011) which showed that outcomes of formal education in the form of skills may assist in the successful completion of the identification and exploitation phase. In the South African context, entrepreneurship education is lacking (Herrington et al. 2014) and as a result, entrepreneurs appear to use skills acquired

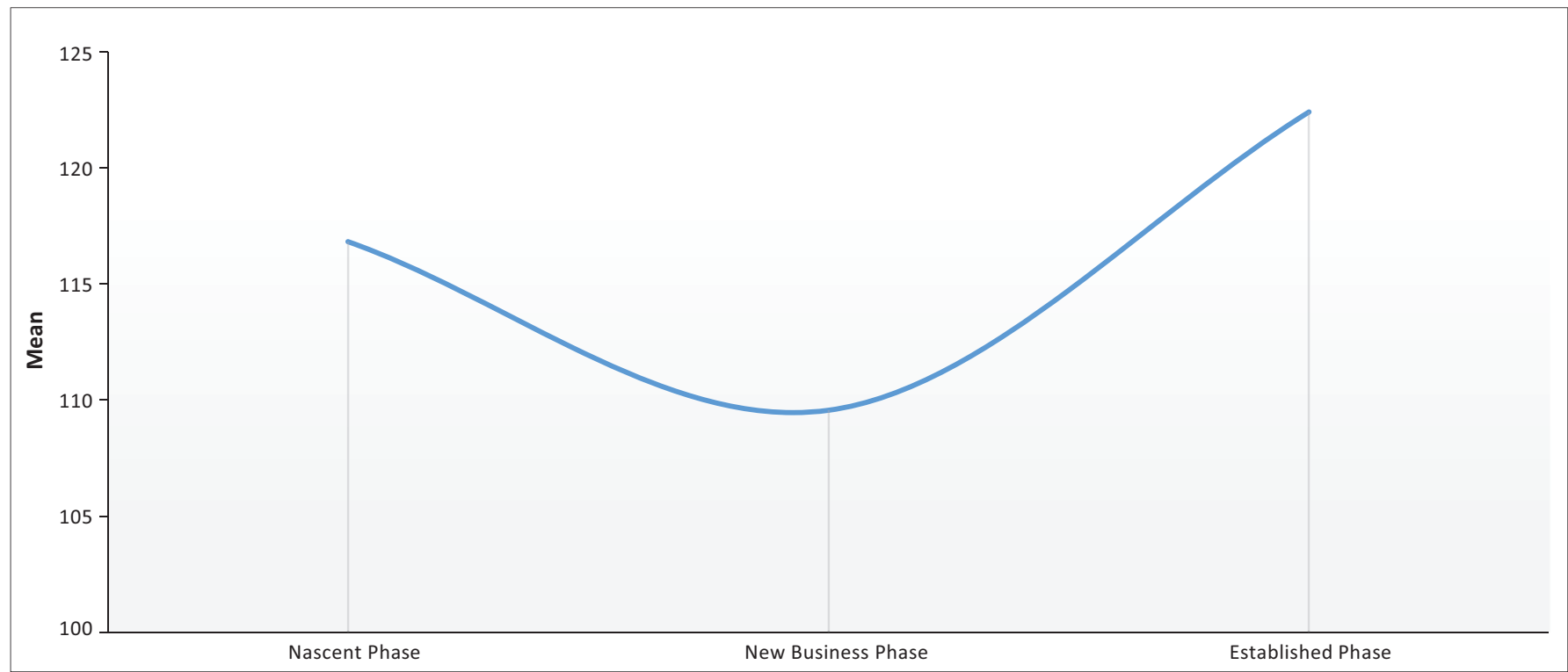

FIGURE 2: Human capital investments utility across the entrepreneurship phases. 


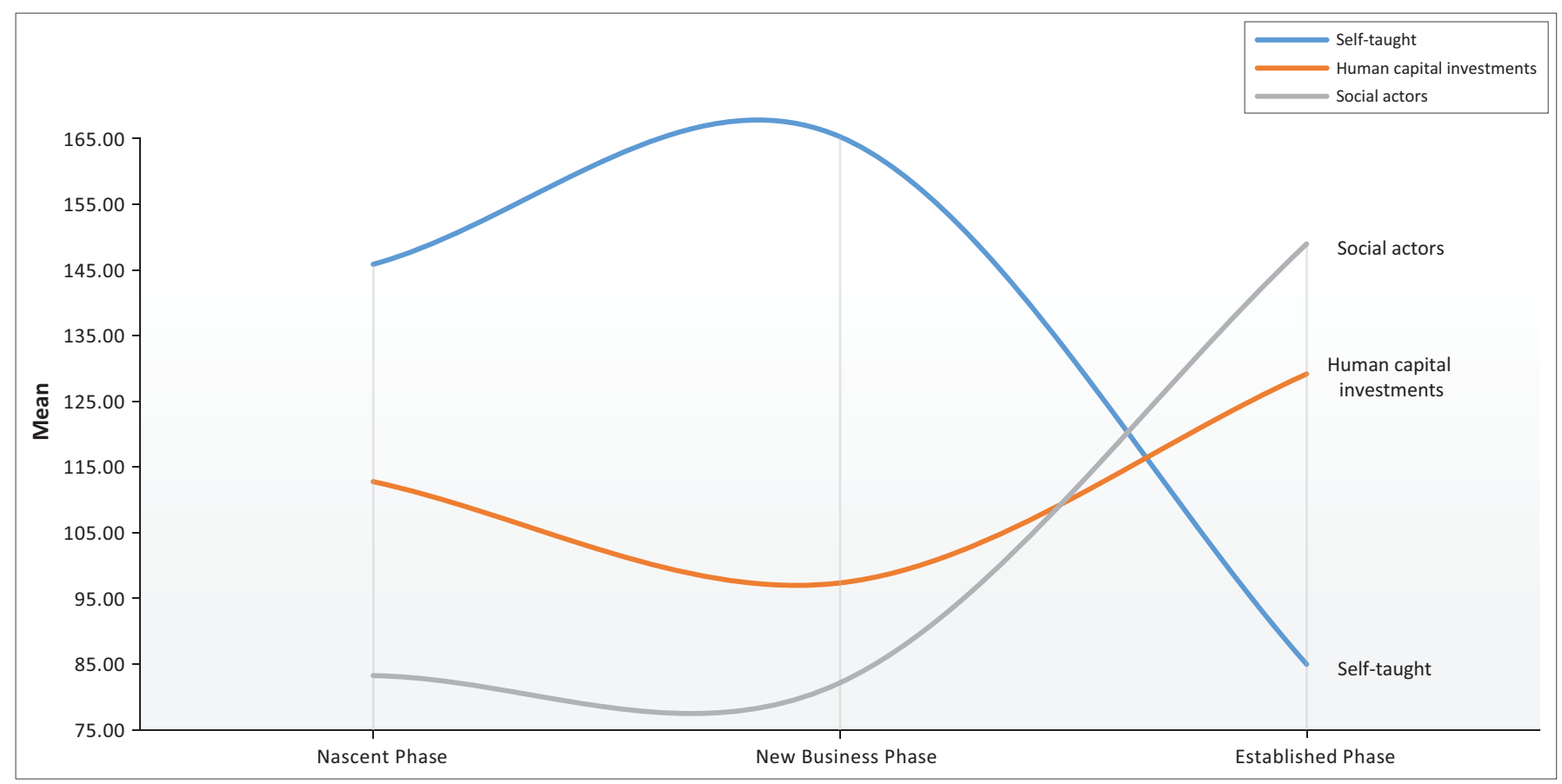

FIGURE 3: Sources of skills across the entrepreneurship phases.

from formal education to identify and exploit entrepreneurial opportunities.

\section{Hypothesis 2: Work experience}

There was no statistically significant difference in the use of skills acquired from work experience across all the entrepreneurship phases; therefore, Hypothesis 2 was not supported. Entrepreneurs in all entrepreneurship phases used skills from work experience. Contrary to Davidsson and Honig (2003) who noted that work experience is not significant for the exploitation of opportunity, the findings in this study demonstrated that work experience is significant in the nascent phase, new business phase and to some extent in the established phase.

\section{Hypothesis 3: Prior entrepreneurship experience}

Although use of prior entrepreneurial experience as a source of skills across entrepreneurship phases is notably different, the hypothesis was partially supported on the notion that entrepreneurs in the established phase were more likely to apply skills learnt from previous entrepreneurship experience than entrepreneurs in the nascent and new business phases. The established entrepreneurs use skills developed during previous entrepreneurial experiences to start and run new business ventures. The results are in line with Dimov's study (2010) that established and repeat entrepreneurs use the skills acquired from prior entrepreneurship experience to start and run new business ventures. Similar to this study's findings, experienced or established entrepreneurs have developed mental frameworks which make the application of some of the skills like opportunity recognition and decision-making easier (Cassar 2014; Ucbasaran et al. 2008).

\section{Hypothesis 4: Entrepreneurship education}

The results showed that there was a significant difference in the application of skills acquired from entrepreneurship education across the phases. Because entrepreneurs running established businesses used skills learnt from entrepreneurship education to a greater extent than those in the nascent and new business phases, the hypothesis was partially supported. As the business environment changes, established entrepreneurs periodically update their skills by attending management programmes (Martin et al. 2013).

Considering the South African macro context in which the study was conducted, which is characterised by poor to absent entrepreneurial education at secondary and tertiary levels (Turton \& Herrington 2012), some of the entrepreneurs in the start-up phase have nothad access to any entrepreneurial education; thus, they largely use skills learnt from formal education to start and run their businesses. This makes formal education significant throughout the entrepreneurship phases. Because formal education does not contribute to sustenance of a business (Davidsson \& Honig 2003), this may contribute to the high failure rate of businesses in South Africa (Turton \& Herrington 2012). In addition, Botha and Bignotti (2016) highlighted that tertiary entrepreneurship education should include internship programmes. In their empirical study, they discovered that there is a positive influence of internships on entrepreneurial intent and entrepreneurial self-efficacy. Therefore, South Africa has a challenge of investing and introducing entrepreneurship education in schools and tertiary institutions.

\section{Hypothesis 5a: Family and friends}

The hypothesis was partially supported as the results of this study indicated that entrepreneurs in the established phase 
applied skills learnt from family and friends to a greater extent than entrepreneurs in the nascent and new business phases. An explanation is that in a context of low levels of entrepreneurial activity, most individuals who start businesses do not come from entrepreneurial families. Although family and friends may serve as sources of funding and effective support (Greve \& Salaff 2003; Lamine et al. 2015), if they are not entrepreneurial, they are less likely to be able to offer relevant entrepreneurship skills and advice. Therefore, in a context of high entrepreneurial activity, where family and friends are entrepreneurial, the nascent entrepreneur will rely on these as sources of skills needed to start a business.

\section{Hypothesis 5b: Mentors and coaches}

The hypothesis was partially supported because entrepreneurs in the established phase applied skills learnt from mentors and coaches to a greater extent than entrepreneurs in the nascent and new business phases. Experienced entrepreneurs have better access to other successful entrepreneurs and consultants who may serve as coaches and mentors. Because entrepreneurs in the nascent phase have poor access to mentorship and coaching, they rely on self-taught skills which are acquired from reading about other entrepreneurs. Some of the nascent entrepreneurs may be overconfident and may not seek mentorship (Invernizzi et al. 2016). As the businesses grow, entrepreneurs use skills obtained from mentors and coaches represented by bridging social capital (Putnam 2001; Stam, Arzlanian \& Elfring 2014). The findings relating to the unequal role of social networks as sources of skills are supported by Huggins et al. (2015) who demonstrated that the role of social networks in the entrepreneurship phases, that is, emergent phase, growth phase and mature phase is different.

\section{Hypothesis 6a: Failure and mistakes}

Entrepreneurs in the nascent and new business phases were more likely to apply skills learnt from failures and mistakes made in the process of starting and establishing their businesses than entrepreneurs in the established phase; therefore, the hypothesis was supported. This suggests that nascent entrepreneurs learn from failure through trial and error in the process of establishing a business venture. During the process of experimentation, others discover that those initial ideas that lead to the start-up are not so great, and therefore they may decide to abandon the ideas or exit the entrepreneurship process (Dimov 2010; Kelley et al. 2012). Therefore, the current systems of supporting and financing nascent and new business entrepreneurs need to accept failure as a necessary part of the journey to successful business venturing.

\section{Hypothesis 6b: Reading books}

The hypothesis was supported as the results showed that the usage of skills or practices acquired from reading entrepreneurial books was found to be different across the entrepreneurship phases. The study's findings are in line with the notion that nascent and new business entrepreneurs model entrepreneurs' stories they read in the media and apply what worked for them (Aldrich \& Yang 2014; Baron \& Ensley 2006; Rae 2005). Also, because nascent entrepreneurs have self-confidence in their own skills, they try out things by themselves and do not seek help (Markman \& Baron 2003; Robinson \& Marino 2015). This is why some of them read the success stories of other entrepreneurs. On the contrary, copying what other entrepreneurs in different business contexts did may lead to failure in the nascent phase. Therefore, the study suggests that because of lack of resources in the nascent phase, nascent entrepreneurs adopt skills in opportunity recognition, decision-making, venture creation and growing the business by reading about what other entrepreneurs applied.

\section{Conclusions and practical implications}

This study made a contribution by advancing on the human capital theory that human capital investments and skills outcomes change in significance in the different entrepreneurship phases. An argument raised in the literature review is that the utility of human capital investments as a source of skills is unequal across the differententrepreneurship phases. Indeed, the findings of this study confirmed that the application of skills acquired from human capital investments is different in the nascent, new business and established business phases. This simply suggests that human capital is not static and linear, but it is dynamic, curvilinear and changes over the entrepreneurship phases.

The results showed that entrepreneurship education is significant in the skills development of entrepreneurs, and therefore the teaching of entrepreneurship should be emphasised, especially to nascent and new business phases that do not have access. The teaching of entrepreneurship can be another way of improving the levels of formal education. Because it was observed that the context of the study had a poor entrepreneurship education track record, the academic and training institutions should incorporate entrepreneurship development in the curriculum as early as primary school and maintain it throughout secondary and tertiary education. This will equip nascent entrepreneurs with the depth of skill required to start and maintain business.

It was found that nascent entrepreneurs rely mostly on selftaught skills as they do not have access to coaching and mentoring so the government, private sectors and successful entrepreneurs can offer mentoring and coaching to the nascent entrepreneurs so as to minimise failure. This is because the criteria used by enterprise development institutions target established entrepreneurs than those in the nascent phases. To make it to some of the programmes, the business should be making a certain amount of profit, which at times is not attainable in the nascent phases. Therefore, the enterprise development institutions such as universities, 
governmental and private organisations need to start focusing on nascent and new business entrepreneurs who have a higher need of skills. This shift in focus could reduce the failure rate of businesses in the early phases of the entrepreneurship process.

This study was not able to determine the skills learnt from each type of human capital investment; therefore, future studies should focus on what are the types of skills learnt from these investments. Obtaining the required sample sizes for nascent and new business phase entrepreneurs was a challenge because most start-up businesses are not formally registered and it is difficult to access databases from some entrepreneurial incubators; therefore, future studies should aim at obtaining larger samples of nascent entrepreneurs. The research was positioned in a context characterised by low entrepreneurial activity and low skills levels; therefore, the study may be less generalizable in contexts where entrepreneurial activity and skills are very high.

\section{Acknowledgements Competing interests}

The authors declare that they have no financial or personal relationships which may have inappropriately influenced them in writing this article.

\section{Authors' contributions}

M.A.M. conducted the research study, literature review and wrote the first draft of the article. M.K. and T.K. contributed to the conceptualisation of the theoretical framework and interpretation of the research findings.

\section{References}

Aldrich, H.E. \& Yang, T., 2014, 'How do entrepreneurs know what to do? Learning and organizing in new ventures', Journal of Evolutionary Economics 24(1), 59-82. https://doi.org/10.1007/s00191-013-0320-x

Amorós, J.E. \& Bosma, N., 2014, Global entrepreneurship monitor 2013 global report, Global Entrepreneurship Research Association, Wellesley, MA.

Baptista, R., Karaöz, M. \& Mendonça, J., 2013, 'The impact of human capital on the early success of necessity versus opportunity-based entrepreneurs', Smal Business Economics 42(4), 831-847. https://doi.org/10.1007/s11187-013-9502-z

Baron, R.A. \& Ensley, M.D., 2006, 'Opportunity recognition as the detection of meaningful patterns: Evidence from comparisons of novice and experienced entrepreneurs', Management Science 52(9), 1331-1344. https://doi.org/10.1287/ mnsc.1060.0538

Becker, G.S., 1964, Human capital: A theoretical and empirical analysis, with special reference to education, National Bureau of Economic Research, New York.

Bergmann, H. \& Stephan, U., 2013, 'Moving on from nascent entrepreneurship: Measuring cross-national differences in the transition to new business ownership', Small Business Economics 41(4), 945-959.

Bosma, N., Van Praag, M., Thurik, R. \& De Wit, G., 2004, 'The value of human and social capital investments for the business performance of startups', Small Business Economics 23(3), 227-236. https://doi.org/10.1023/B:SBEJ.0000032032.21192.72

Botha, M. \& Bignotti, A., 2016, 'Internships enhancing entrepreneurial intent and selfefficacy: Investigating tertiary-level entrepreneurship education programmes' Southern African Journal of Entrepreneurship and Small Business Management 8(1), a45. https://doi.org/10.4102/sajesbm.v8i1.45

Brixy, U., Sternberg, R. \& Stüber, H., 2012, 'The selectiveness of the entrepreneuria processes', Journal of Small Business Management 50(1), 105-131. https://doi. org/10.1111/j.1540-627X.2011.00346.X

Carter, N.M., Gartner, W.B. \& Reynolds, P.D., 1996, 'Exploring start-up event sequences', Journal of Business Venturing 11(3), 151-166. https://doi.org/10. 1016/0883-9026(95)00129-8

Cassar, G., 2014, 'Industry and startup experience on entrepreneur forecast performance in new firms', Journal of Business Venturing 29(1), 137-151. https:// doi.org/10.1016/j.jbusvent.2012.10.002
Chang, W.L., Liu, J.Y. \& Huang, W.G., 2014, 'A study of the relationship between entrepreneurship courses and opportunity identification: An empirical survey', Asia Pacific Management Review 19(1), 1-24.

Cunningham, J.B. \& Aldrich, J.O., 2011, Using SPSS: An interactive hands-on approach, Sage Publications, London.

Dash, M. \& Kaur, K., 2012, 'Youth entrepreneurship as a way of boosting Indian economic competitiveness: A study of Orissa', International Review of Management and Marketing 2(1), 10-21.

Davidsson, P. \& Honig, B., 2003, 'The role of social and human capital among nascent entrepreneurs', Journal of Business Venturing 18(3), 301-331. https://doi.org/10. 1016/S0883-9026(02)00097-6

Dimov, D., 2010, 'Nascent entrepreneurs and venture emergence: Opportunity confidence, human capital, and early planning', Journal of Management Studies 47(6), 1123-1153. https://doi.org/10.1111/j.1467-6486.2009.00874.x

Eesley, C. \& Wang, Y., 2017, 'Social influence in career choice: Evidence from a randomized field experiment on entrepreneurial mentorship', Research Policy 46(3), 636-650. https://doi.org/10.1016/j.respol.2017.01.010

Elmuti, D., Khoury, G. \& Omran, O., 2012, 'Does entrepreneurship education have a role in developing entrepreneurial skills and ventures' effectiveness?' Journal of Entrepreneurship Education 15(1), 83-98.

Gabrielsson, J. \& Politis, D., 2012, 'Work experience and the generation of new business ideas among entrepreneurs: An integrated learning framework', International Journal of Entrepreneurial Behaviour \& Research 18(1), 48-74. https://doi.org/10.1108/13552551211201376

Ganotakis, P., 2012, 'Founders' human capital and the performance of UK new technology based firms', Small Business Economics 39(2), 495-515. https://doi. org/10.1007/s11187-010-9309-0

Gimeno, J., Folta, T.B., Cooper, A.C. \& Woo, C.Y., 1997, 'Survival of the fittest? Entrepreneurial human capital and the persistence of underperforming firms', Administrative Science Quarterly 42, 750-783. https://doi.org/10.2307/2393656

Greve, A. \& Salaff, J.W., 2003, 'Social networks and entrepreneurship', Entrepreneurship Theory and Practice 28(1), 1-22. https://doi.org/10.1111/1540-8520.00029

Herrington, M. \& Kew, P., 2017, GEM 2016/17 global report, Global Entrepreneurship Research Association (GERA), Wellesley, MA.

Herrington, M., Kew, J. \& Kew, P., 2014, GEM 2014 Sub-Saharan Africa Report, Global Entrepreneurship Research Association, Cape Town.

Huggins, R., Izushi, H., Prokop, D. \& Thompson, P., 2015, 'Network evolution and the spatiotemporal dynamics of knowledge sourcing', Entrepreneurship \& Regional Development 27(7-8), 474-499. https://doi.org/10.1080/08985626.2015.1070538

Invernizzi, A.C., Menozzi, A., Passarani, D.A., Patton, D. \& Viglia, G., 2016 'Entrepreneurial overconfidence and its impact upon performance', Internationa Small Business Journal 1-20. https://doi.org/10.1177/0266242616678445

Kelley, D., Singer, S. \& Herrington, M., 2012, GEM 2011 global report, Global Entrepreneurship Research Association (GERA), Wellesley, MA.

Kirzner, I.M., 1973, Competition and entrepreneurship, University of Chicago Press, Chicago, IL.

Lamine, W., Jack, S., Fayolle, A. \& Chabaud, D., 2015, 'One step beyond? Towards a process view of social networks in entrepreneurship', Entrepreneurship \& Regional Development 27(7-8), 413-429. https://doi.org/10.1080/08985626.2015.1070535

Likert, R., 1932, 'A technique for the measurement of attitudes', Archives of Psychology 22, 5-55.

Man, T.W., Lau, T. \& Chan, K., 2002, 'The competitiveness of small and medium enterprises: A conceptualization with focus on entrepreneurial competencies' Journal of Business Venturing 17(2), 123-142. https://doi.org/10.1016/S08839026(00)00058-6

Markman, G.D. \& Baron, R.A., 2003, 'Person-entrepreneurship fit: Why some people are more successful as entrepreneurs than others', Human Resource Management Review 13(2), 281-301. https://doi.org/10.1016/S1053-4822(03)00018-4

Martin, B.C., McNally, J.J. \& Kay, M.J., 2013, 'Examining the formation of human capital in entrepreneurship: A personal-analysis of entrepreneurship education outcomes', Journal of Business Venturing 28(2), 211-224. https://doi. org/10.1016/j.jbusvent.2012.03.002

Marvel, M.R., Davis, J.L. \& Sproul, C.R., 2014, 'Human capital and entrepreneurship research: A critical review and future directions', Entrepreneurship Theory and Practice 40(3), 599-626. https://doi.org/10.1111/etap.12136

McMullen, J.S. \& Dimov, D., 2013, 'Time and the entrepreneurial journey: The problems and promise of studying entrepreneurship as a process', Journal of Management Studies 50(8), 1481-1512. https://doi.org/10.1111/joms.12049

Moroz, P.W. \& Hindle, K., 2012, 'Entrepreneurship as a process: Toward harmonizing multiple perspectives', Entrepreneurship Theory and Practice 36(4), 781-818. https://doi.org/10.1111/j.1540-6520.2011.00452.x

Morris, M.H., Kuratko, D.F., Schindehutte, M. \& Spivack, A.J., 2012, 'Framing the entrepreneurial experience', Entrepreneurship Theory and Practice 36(1), 11-40. https://doi.org/10.1111/j.1540-6520.2011.00471.x

Parker, S.C., 2013, 'Do serial entrepreneurs run successively better-performing businesses?', Journal of Business Venturing 28(5), 652-666. https://doi. org/10.1016/j.jbusvent.2012.08.001

Polanyi, M., 1966, 'The logic of tacit inference', Philosophy 41(155), 1-18. https://doi. org/10.1017/S0031819100066110

Politis, D., 2008, 'Does prior start-up experience matter for entrepreneurs' learning? A comparison between novice and habitual entrepreneurs', Journal of Small Business and Enterprise Development 15(3), 472-489. https://doi.org/10.1108/ Business and Enterprise
14626000810892292 
Putnam, R.D., 2001, Bowling alone: The collapse and revival of American community, Simon and Schuster, New York.

Rae, D., 2005, 'Entrepreneurial learning: A narrative-based conceptual model', Journal of Small Business and Enterprise Development 12(3), 323-335. https://doi. org/10.1108/14626000510612259

Reynolds, P.D. \& Curtin, R.T., 2008, 'Business creation in the states: Panel study of entrepreneurial dynamics II initial assessment', Foundations and Trends in Entrepreneurship 4(3), 155-307. https://doi.org/10.1561/0300000022

Robinson, A.T. \& Marino, L.D., 2015, 'Overconfidence and risk perceptions: Do they really matter for venture creation decisions?', International Entrepreneurship and Management Journal 11(1), 149-168. https://doi.org/10.1007/s11365-013 0277-0

Shane, S., 2000, 'Prior knowledge and the discovery of entrepreneurial opportunities', Organization Science 11(4), 448-469. https://doi.org/10.1287/orsc.11.4.448. 14602

Shane, S. \& Venkataraman, S., 2000, 'The promise of entrepreneurship as a field of research', Academy of Management Review 25(1), 217-226. https://doi.org/10. 2307/259271

Shane, S.A., 2003, A general theory of entrepreneurship: The individual-opportunity nexus, Edward Elgar Publishing, Northampton, MA.

Silva, O., 2007, 'The jack-of-all-trades entrepreneur: Innate talent or acquired skill?', Economics Letters 97(2), 118-123. https://doi.org/10.1016/j.econlet.2007. 02.027

Singer, S., Amorós, J.E. \& Moska, D., 2015, GEM 2014 global report, Global Entrepreneurship Research Association, Wellesley, MA.

Stam, W., Arzlanian, S. \& Elfring, T., 2014, 'Social capital of entrepreneurs and small firm performance: A meta-analysis of contextual and methodological moderators', Journal of Business Venturing 29(1), 152-173. https://doi.org/10.1016/j.jbusvent. 2013.01.002

Stenholm, P., Acs, Z.J. \& Wuebker, R., 2013, 'Exploring country-level institutional arrangements on the rate and type of entrepreneurial activity', Journal of Business Venturing 28(1), 176-193. https://doi.org/10.1016/j.jbusvent.2011. 11.002

St-Jean, É., Tremblay, M., Janssen, F., Baronet, J., Loué, C. \& Nafa, A., 2016, 'May business mentors act as opportunity brokers and enablers among university students?', International Entrepreneurship and Management Journal, 13(1), 1-15.
Stuetzer, M., Goethner, M. \& Cantner, U., 2012, 'Do balanced skills help nascent entrepreneurs to make progress in the venture creation process?' Economics Letters 117(1), 186-188. https://doi.org/10.1016/j.econlet.2012.05.002

Tashakkori, A. \& Teddlie, C., 2003, Handbook of mixed methods in social \& behavioral research, Sage, London.

Teddlie, C. \& Yu, F., 2007, 'Mixed methods sampling a typology with examples', Journal of Mixed Methods Research 1(1), 77-100. https://doi.org/10.1177/ 2345678906292430

Toft-Kehler, R., Wennberg, K. \& Kim, P.H., 2014, 'Practice makes perfect Entrepreneurial-experience curves and venture performance', Journal of Business Venturing 29(4), 453-470. https://doi.org/10.1016/j.jbusvent.2013.07.001

Trevelyan, R., 2011, 'Self-regulation and effort in entrepreneurial tasks', International Journal of Entrepreneurial Behavior \& Research 17(1), 39-63. https://doi.org/10 1108/13552551111107507

Turton, N. \& Herrington, M., 2012, Global entrepreneurship monitor 2012 South Africa, Global Entrepreneurship Research Association, Cape Town.

Ucbasaran, D., Westhead, P. \& Wright, M., 2008, 'Opportunity identification and pursuit: Does an entrepreneur's human capital matter?', Small Business Economics 30(2), 153-173. https://doi.org/10.1007/s11187-006-9020-3

Unger, J.M., Rauch, A., Frese, M. \& Rosenbusch, N., 2011, 'Human capital and entrepreneurial success: A personal-analytical review', Journal of Business Venturing 26(3), 341-358. https://doi.org/10.1016/j.jbusvent.2009.09.004

Van der Sluis, J., Van Praag, M. \& Vijverberg, W., 2008, 'Education and entrepreneurship selection and performance: A review of the empirical literature', Journal of Economic Surveys 22(5), 795-841. https://doi.org/10.1111/j.1467-6419. 2008.00550.x

Wasdani, K.P. \& Mathew, M., 2014, 'Potential for opportunity recognition along the stages of entrepreneurship', Journal of Global Entrepreneurship Research 2(1), 7 https://doi.org/10.1186/2251-7316-2-7

Wiklund, J., Davidsson, P., Audretsch, D.B. \& Karlsson, C., 2011, 'The future of entrepreneurship research', Entrepreneurship Theory and Practice 35(1), 1-9. https://doi.org/10.1111/j.1540-6520.2010.00420.x

World Bank, 2012, World development report 2013: Jobs, World Bank, Washington, DC.

Yusuf, J.E., 2012, 'Why do nascent entrepreneurs use external assistance programs?', Journal of Entrepreneurship and Public Policy 1(2), 166-182. https://doi.org/10. $1108 / 20452101211261444$ 